\title{
DIFFERENT APPROACHES TO DEFINING METROPOLITAN AREAS (CASE STUDY: CITIES OF BRNO AND OSTRAVA, CZECH REPUBLIC)
}

\author{
Petr TONEV ${ }^{I}$, Zdeněk DVO \\ CHALOUPKOVÁ ${ }^{I}, Z$ deněk ŠILHAN ${ }^{I}$
}

DOI: $10.21163 / G T \_2017.121 .11$

\begin{abstract}
:
The definition and delimitation of metropolitan areas has been the focus of many geographers and other specialists for quite a few decades. The complexity and diversity of the methods and techniques used, and the differing attitudes of those working in this area have brought considerably different, and often controversial, results. The EU has introduced a tool, Integrated Territorial Investments (ITI), to support study in this area by motivating EU member states to define their metropolitan areas. This article will introduce the methodological approaches related to the functional integration of regional units and to inter-regional relations, used with ITI to delimit the metropolitan areas in two large cities, Brno (monocentric system) and Ostrava (polycentric system), and will compare the results with those achieved using our own method. Through a comparison of the results this article will examine the efficacy of the methods previously used and their possible transferability to studies of metropolitan areas with completely different settlement systems. Finally, this article will consider whether a unification of previously fragmented approaches is possible.
\end{abstract}

Key words: Metropolitan areas, Methods of Delimitation, Integrated Territorial Investment, Czech Republic

\section{INTRODUCTION}

Defining metropolitan areas is a relatively complicated technical and statistical matter in the geographical sciences. The method, or methods, used depend on not only the availability of statistical data, spatial perspective and other area specifics, but also on the author's original approach. If certain methodical rules are maintained, even considerably different approaches can be considered relevant.

The first studies by the American Bureau of the Census published in the first two decades of the twentieth century, introduced a system for the territorial classification of the so-called Metropolitan districts. Metropolitan districts were defined as cities with over 200 thousand inhabitants, or rather as cities with over 50 thousand inhabitants when redefined in the 1940s (Berry, 1973). After the Second World War further distinctions were made with new definitions for Standard Metropolitan Areas (SMA), or rather Standard Metropolitan Statistical Areas (SMSA) along with some other revisions in the second half of the twentieth century (Dahmann, 1999). It was the work of the American geographer, B.J.L. Berry (1968 et al., 1973), in the 1960s and 1970s which laid the foundations for the more detailed expansion of the city-region concept as a daily urban system (DUS), or more precisely a functional urban region (FUR). Hall et al. (1973) continued Berry's work and the concept of FUR spread to Great Britain and Europe particularly to researchers in two

\footnotetext{
${ }^{1}$ Masaryk University, Faculty of Economics and Administration, 60200 Brno, Czech Republic, tonev@econ.muni.cz;dvorak.zdenek@mail.muni.cz;206708@mail.muni.cz; kunc@econ.muni.cz; 390728@mail.muni.cz; z.silhan@mail.muni.cz.
} 
institutions - the University of Reading and International Institute for Applied Systems Analysis (IIASA) in Laxenburg, Austria. The latter aimed to establish a framework for FUR to provide a better understanding of the impact of public policy on the fields of population distribution and economic development. Partial studies done in western European countries (e.g. Great Britain, Sweden) became the basis for monograph by Hall \& Hay (1980), which was extended by Cheshire \& Hay (1989). Case studies of other countries, processed in Laxenburg, became part of a publication by Kawashima \& Korcelli (1982), or were published separately, i.e. by Sherill $(1976,1977)$. Coombes et al. (1978, 1982) were working on the concept of FUR in parallel with these studies. The papers mentioned here defined the borders of city-regions per their extensive daily influx of commuters (that is if the data were available, if not, models of interactions were used). Two main factors determined the choice of work-related commuting: firstly, there was insufficient other data representing inter-regional links; and secondly, work commuting appropriately reflected the space structures of inter-regional contact, especially in the tertiary sector.

More modern literature includes particularly case studies of selected metropolitan areas from across most continents. Western Europe represents for example García-Palomares (2010) that analyses the relationship between urban sprawl and commuting to work in the case of Madrid, with three elements of urban sprawl considered: metropolitan expansion; low-density of work and leisure facilities in suburban areas. Veneri (2013) uses functional approach with stress on morphological criteria (a similar approach as ours) to delimit subcentres in Rome and Milan metropolitan areas. To identify functional urban regions within traffic flow in London, Manley (2014) applies community detection algorithms to a topological representation of the road network formed through observed routing behaviour. Boix et al. (2012) attempt to show that there is a homogenous suggestion of delimitation for polycentric metropolitan areas in Europe. They are hampered by insufficient data and the inconvenience of administrative borders when defining metropolitan areas, however, they do attempt to define the so-called Dynamic Metropolitan Areas (DMAs) using European capitals as examples, primarily on the grounds of work commuting between centre parts of metropolitan areas. Brezzi et al. (2012) successively compare selected metropolitan areas in the countries of the OECD and introduce the concept of Metropolitan Regions. Using special BBSR Accesibility Model, Göddecke-Stellmann (2011) defines 125 metropolitan areas in Europe (polycentric spatial segments), whereas prioritises regional level than LAU 2 level. A car travel time of one hour is fixed around all cores defining the external border of a metropolitan area. New method of delineation U.S. metropolitan and micropolitan statistical areas (collectivelly core-based statistical areas - CBSA) was published by Tong $\&$ Plane (2014). Their approach is based on clustering of counties with regard to the strength of commuting interactions between outlying areas and urban cores. Model seeks to find the boundaries that maximize the containment of entire webs of intra-CBSA intercounty commuting. South America is represented, for example, by the works of Duranton $(2015 \mathrm{a}, 2015 \mathrm{~b})$. In both studies of the urban environment of Colombia, the author notes the necessity of defining metropolitan areas and subsequently argues for the use of a simple algorithm that exploits cross-municipality commuting patterns.

Many scholarly studies were initiated in recent years in Asia. Kanemoto \& Kurima (2006) use the example of Japan to demonstrate an increasingly important and formerly almost unaddressed problem connected to the emergence of many subcenters because of increasingly complex commuting patterns. Liu et al. (2010) use a method of quantitative delimitation of the metropolitan area (Lanzhou, Northwest China), which is based on a 
synthetic method in conjunction with geographical information system (GIS) technology. This method were applied according to the analysis of spatial attenuating tendency, economic gravity, network, civil interest and potential effect. Almost a pioneering method implemented in his paper Zhen et al. (2017). Delineation of an urban agglomeration boundary in Yangtze River Delta Metropolitan region (East China, biggest city Shanghai) they based on one of the most popular website in China, Sina Weibo microblog (hybrid of Twitter and Facebook), and 1,5 million valid „,check-in“ records analyzing activity data (activity intensity, closeness and connection). Although the authors are aware of number of methodological limits (especially data bias), they determined much smaller space of research area than that based on the administrative division.

Regional politics and spatial planning systems have an increasingly important role in the delineation of metropolitan areas or regions. Benedek (2016) and Török (2015) in their studies concern about evaluation the process and outcome of establishing the urban growth poles as key elements of the new Regional policy in Romania. Swianiewicz \& Lackowska (2007) again draw attention to the passive role of the state (Poland) in the formation of metropolitan governance. Despite the relatively frequent criticism of the contemporary EU territorial cohesion policy coming especially from Central and Eastern Europe, mentioning its late outset and some of its aspects being reminiscent of socialist central planning (e.g. Török, 2015; Malý \& Mulíček, 2016), we side with the opinion of other authors on the importance and the necessity of supporting regional policy in its efforts to define and delineate metropolitan areas and gradually institutionalize them.

In the Czech Republic defining of metropolitan areas was not any common in the past. In the last two decades situation has been changing, specialists have shown increasing interest in this issue, for example, Dostál \& Hampl (2002), Kostelecký \& Čermák (2004), Hampl (2005), Čermák et al. (2009), Fixel et al. (2009), Sýkora \& Mulíček (2009), HruškaTvrdý (2012), Mulíček et al. (2013), Pařil et al. (2015), Kladivo et al. (2015), Dvořák (2015) or Klapka et al. (2016). Despite certain differences in the results obtained (see Table 1. with data from the metropolitan areas of Brno and Ostrava), all the studies are based upon statistically relevant data. The differences come from the method selected and the interpretation of the applied indicators.

The European Union played (e.g. final report of ESPON: "The Role of Small and Medium-Sized Towns"; ÖIR, 2006) and recently plays an important role in motivating member states to define their metropolitan areas through ITI tool. This shows how current policy can strengthen territorial dimensions using integrated tools to develop urban and rural regions (i.e. Ouředníček et al., 2015). As stated in the "Methodological directive for the use of integrated tools during the period 2014-2020" (Ministry of Regional Development of the Czech Republic), there are four metropolitan areas with a number of inhabitants over 300 thousand in the Czech Republic: Praha, Brno, Ostrava and Plzeň. Each area choses its methods individually, which contributes to the problem of fragmentation in the current approach to defining metropolitan areas. It is obvious that many of the above mentioned authors occupy two basic problems with which we also identify in our paper: i) own definitions of metropolitan areas (with regard to the specifics of the territory), and ii) the existence and relevance of the statistical data. The aim of this article is to introduce the methodological approaches and results obtained through the ITI tool to define the metropolitan areas of Brno and Ostrava, and compare them with the results of our method. The efficacy of both of these methodological approaches, as well as their interpretation and possible transferability to completely different settlement systems will be discussed based on a comparison of the results obtained. 


\section{METHODS AND RESULTS}

As mentioned in the opening chapter, for ITI it is necessary that the member states or chosen metropolitan areas fulfil certain conditions, such as giving an individual definition of the metropolitan area based on an adequate method and the formulation of Integrated strategies for the development of metropolitan areas. The authors of this article are going to present their own method, with the ambition that it might help to unify and universalise the so far rather fragmented methods. The method of Mulíček et al. (2013), who have defined Brno's metropolitan area (BMA), and the method of Kladivo et al. (2015), who have defined Ostrava's metropolitan area (OMA), both using ITI, will be introduced and compared with our approach. These two areas were chosen for their diversity so that the methods could be compared and tested effectively. Their centres are the second (Brno) and the third (Ostrava) largest cities in the Czech Republic, and are about the same size (approximately 380 and 300 thousands of inhabitants respectively), while the settlement structure of these cities is completely different. In Brno, there is a considerable lack of a rival centre; the outskirts are formed by more or less rural areas and so the inter-settlement bonds are of a rather radial structure. On the contrary, thanks to massive industrialization, Ostrava and its surroundings represent a highly-urbanized region with a vast concentration of cities, some with a specific role in the settlement system (residential, working or services). Relations between the settlements are intensive and bidirectional with a different degree of asymmetry.

The basic spatial unit for defining metropolitan areas, used in all three of these methods, is a municipality. This is the smallest territorial unit for which we can find data connected to work and school commuting, or migration. The Czech Republic has approximately 6,250 municipalities, with average areas and populations among the smallest in Europe.

Mulíček et al. (2013) have selected the following indicators:

1. work commuting $\left(\mathrm{TTWA}^{2}\right.$; analysis of the significant flows; and the share of economically-active citizens commuting to Brno),

2. school commuting (the share of children aged from 6 to 14 years commuting to Brno; and the direction and volume of the significant flow towards schools outside of Brno),

3. migration flows (the spatial gathering of municipalities based on the biggest migration relationship, using the method of INTRAMAX; and the identification of important immigration and emigration flows),

4. accessibility of public transport (the frequency and number of connections),

5 . frequency of transport by personal car.

It is possible to divide these indicators into two groups. Numbers one to three show real interactions between the centre area and the surrounding areas, while numbers 4 and 5 indicate potential interaction. The process leading to the definition can be described as:

-narrowing down the area based upon the analysis of work commuting,

-calculating the synthetic indicator of functional interaction, choosing the set of municipalities forming the metropolitan area based on functional interaction levels and the rules of areal integrity, with migration as a controlling function in this process.

Kladivo et al. (2015) have used a combination of quantitative and qualitative indicators to define OMO. Their process can be divided into two steps. The first step is to define

\footnotetext{
${ }^{2}$ Travel to work areas - for more extensive information see Coombes et al. (1986).
} 
centres from a given area. Using quantitative indicators and work commuting data, six centres were gradually determined (Ostrava, Havířov, Karviná, Opava, Frýdek-Místek and Třinec): a fairly large area. The qualitative indicators used are: educational distribution; employment in the high-tech sector; and selected strategic documents concerning the development of the area. Consequently, three more centres of this metropolitan area were determined: Koprrivnice; Nový Jičín; and Příbor. The second step was to assign a background to each centre on the grounds of the following indicators:

1. work commuting,

2. the elimination of suburban and rural areas,

3. regionalization principles transforming the identified areas into continuous ones.

The methods of defining metropolitan areas using ITI in the Czech Republic are individually tailored to each area. However, this does not necessarily undermine the relevance, thoroughness and difficulty of the process. As stated above, this is, to a large extent, a question of methodical approaches.

Now we will focus on our own method, the presentation and comparison of which is the purpose of this article. The following indicators have been used to define the metropolitan areas of Brno and Ostrava:

I. work commuting to the centre area on a daily basis (Czech Statistical Office 2011),

II. overall commuting to high schools in the centre area (Czech Statistical Office, 2011),

III. the migration of the population from municipalities into the centre area or vice versa (during the period from 2010 until 2012) . $^{3}$.

1.Within each indicator, municipalities were individually assigned to a commuting or migration destination based on the strongest commuting/migration flow. This eliminated municipalities with insufficiently significant commuting/migration connections ${ }^{4}$. The process differentiated municipalities and cities into various hierarchic levels, as shown in the following model (Fig. 1).

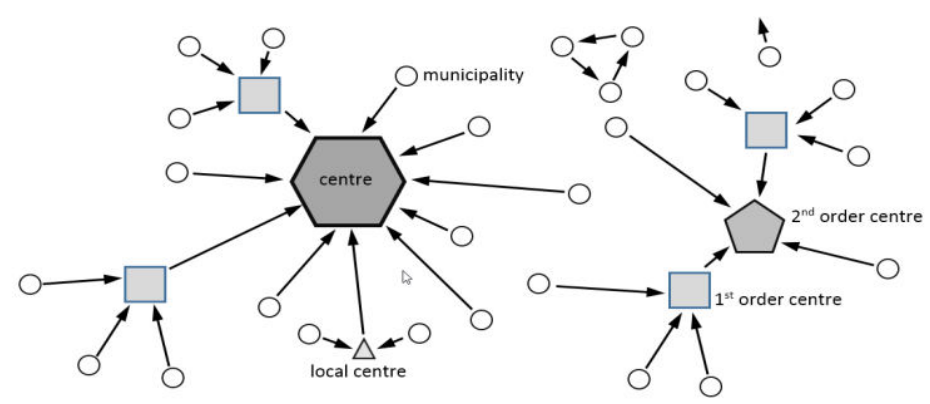

Fig. 1 Model of connections and hierarchic arrangement of municipalities and cities (Source: original work)

\footnotetext{
${ }^{3}$ Unlike work and school commuting, which are still mainly of a centripetal character (i.e. most commuting is from suburban areas), in the case of migration this trend stopped after 1989, and now, primarily due to suburbanization, the prevailing migration is out of the centres (though not necessarily for every municipality). For this reason, we have taken into consideration both directions of travel between municipality and centre.

${ }^{4}$ While under normal circumstances the first step is to define the metropolitan areas based on population size or other characteristics (or a combination of the two), in this case, the centres were determined by the Ministry of Regional Development of the Czech Republic.
} 
A centre of the $1^{\text {st }}$ order is considered to be a municipality that is for at least three municipalities simultaneously:

- the main centre of work commuting,

- the main centre of high school commuting,

- $\quad$ and the main centre of migration connections.

If a municipality was the centre for one or two other municipalities, or for more than three municipalities for just one of the mentioned indicators, it was considered a local centre. A municipality with interactions with one or more centres of the $1^{\text {st }}$ order was considered a municipality of the $2^{\text {nd }}$ order.

2. In this phase, to accurately define a metropolitan area, it was necessary to evaluate whether the centre of the metropolis was more or less autonomous (monocentric system) or, due to strong connections with other important centres (in this case centres of the $2^{\text {nd }}$ order), whether it was part of a polycentric system. It is necessary to mention, that daily work commuting was of crucial importance, because it concerned the largest share of the population (basically all employees), while the other two indicators helped to complete the picture about space interactions (for the available data) in a given area since they either covered a smaller part of the population or were not so intensive (unlike commuting, migration happens in one direction). To assess the area type (whether mono- or polycentric) it was sufficient to use the daily commuting indicator. If the area was of a polycentric structure, a potential secondary centre (in this case a centre of the $2^{\text {nd }}$ order) would comply with following criteria ${ }^{5}$ :

- $\quad$ it must be connected to the main centre by the strongest commuting influx, and this must be sufficiently significant. (at least $5 \%$ of employees have to commute to the main centre),

- relations within a polycentric system must be two-way, i.e. there must be significant reciprocal commuter flow from the main to the secondary centre (if commuter flow to the main centre $=\mathrm{N}$, reciprocal flow out of the main centre must exceed $20 \%$ from $\mathrm{N}$ ),

- connections within a polycentric system must be intensive (the number of reciprocally commuting people on a $1 \mathrm{~km}$ stretch of road between the main and secondary centre must be more than 50$)^{6}$.

In the case of Brno, none of the surrounding centres complied with these criteria, while in case of Ostrava two secondary centres were identified: Karviná and Frýdek-Místek.

Based on this method, Ostrava was evaluated as polycentric with three centres: Ostrava, Karviná, and Frýdek-Místek. Subsequently, these three centres have been subjected to the same analysis as described in point one, this time being considered as one centre with aggregated commuting and migration streams.

\footnotetext{
${ }^{5}$ The criteria were assessed empirically on the grounds of extensive analysis concerning commuting and migration connections within the settlement system of the Czech Republic. To transfer and use the method for other conditions/countries it is possible to adjust particular figures, while maintaining the same principle of criteria.

${ }^{6}$ For the evaluation of reciprocal connections between centres, Hampl (2005) used the value of 75 persons per one $\mathrm{km}$ in a straight line, however most people commute by bus or personal car so it is more precise to consider the real road distance and reduce the limit to 50 people.
} 
3. This phase admitted only such municipalities that complied with the condition of the main commuting/migration flow to the centre area from step one and that complied, at the same time, with the percentage requirements of indicators I-III. In the case of work commuting from a municipality to the centre, an indicator limit was set to $10 \%$ of the employed inhabitants of the municipality, and in the case of high school commuting, a limiting age of 15 to 19 was used. For migration, the limit was set to $1 \%$ of people (inhabitants of a given municipality) moving in both directions between the municipality and the centre. In order to determine the extent of the functional interaction between the municipality and the centre for a certain set of municipalities, each indicator was thoroughly analysed on two levels (altogether there are three pairs of sub-indicators):

I. The share of municipality inhabitants commuting/migrating to the centre, according to:

a) the ratio of those commuting to work to the total number of working inhabitants in a given municipality,

b) the ratio of those commuting to high school to the total inhabitants of a given municipality aged 15 to 19 ,

c) an aggregated value of the migration flows between a municipality and the centre to the total number of inhabitants of that municipality.

II. An analysis of the five strongest flows for each municipality based on each of the three indicators mentioned above. This analysis measured the degree of municipality polarization, i.e. to what extent municipalities were tied by commuting or migration to one or more centres (for more details see Van Nuffel, 2007). The five strongest commuting/migration flows for each municipality were chosen and their volume relativized (\%) according to the total number of commuting/migrating people. Subsequently, these ratios were correlated with model distribution ratios (100-0-0-0-0; 50-50-0-0-0; 33-33-33-0-0; 25-25-25-25-0; 20-20-20-20-20), which were in accordance with having 1, 2, 3, 4 or 5 significant flows going out of a municipality. The number of significant flows was determined on the grounds of this model distribution and the tightest correlation with the real flows. Municipalities had a value from $0.2-1$ assigned. If there was only one important flow (i.e. the tightest correlation was with the first model of 100-0-0-0-0), the value assigned was 1; if there were two flows the value was 0.8 ; three flows $=0.6$, four flows $=0.4$ and five flows $=0.2$.

Afterwards, the values of these six sub-indicators were normalized with help of a MinMax normalization formula: $\mathrm{x}=\left(\mathrm{x}-\min _{\mathrm{x}}\right) /\left(\max _{\mathrm{x}}-\mathrm{min}_{\mathrm{x}}\right)$; so that their value would range between 0.0 to 1.0 .

By adding together the corresponding sub-indicators, three partial pairs of functional integration were obtained - for work commuting, high school commuting and migration - each one in the interval of 0.0-2.0. A value was added to each of these three indicators according to their importance. The value was determined on the grounds of the ratio/proportion of the number of people who are part of the given process in the Czech Republic: ${ }^{7}$

- work commuting

- high school commuting

- migration
0.35

0.45

\footnotetext{
${ }^{7}$ The number of people who commute daily to work and to high school (aged 15-19) across the border of their village was, in 2011, approximately according to the following ratio:

73:12:15 (100 in total).
} 
The three partial pairs of functional integration were multiplied by these coefficients and then added together to obtain a value of overall functional integration in the range of 0.0 to 6.0, while the threshold for municipalities to be included in the metropolitan area was set to a value of 3.0 (according to the number of indicators -3 ).

4. The next step was to match the surrounding areas to the centre of the $1^{\text {st }}$ order or to local centres. If during the previous step such centres reached the value of functional integration of 3.0 or higher, the surrounding municipalities were added to the metropolitan area (even if their strongest commuting or migration connections were not directed towards the centre area).

5. The final definition of the two metropolitan areas was created by the integration of enclaves/exclaves based on the principle of territorial integrity; the resulting area has to be continuous.

Based on this procedure, BMA can be described as monocentric with its centre situated in Brno, with 289 municipalities in the surrounding area, and a total number of inhabitants of 711 thousand. The OMA can be defined as polycentric with three centres, 100 municipalities in the surrounding area and a total of 769 thousand inhabitants (see Fig. 2, Fig. 3 and Table 1.).

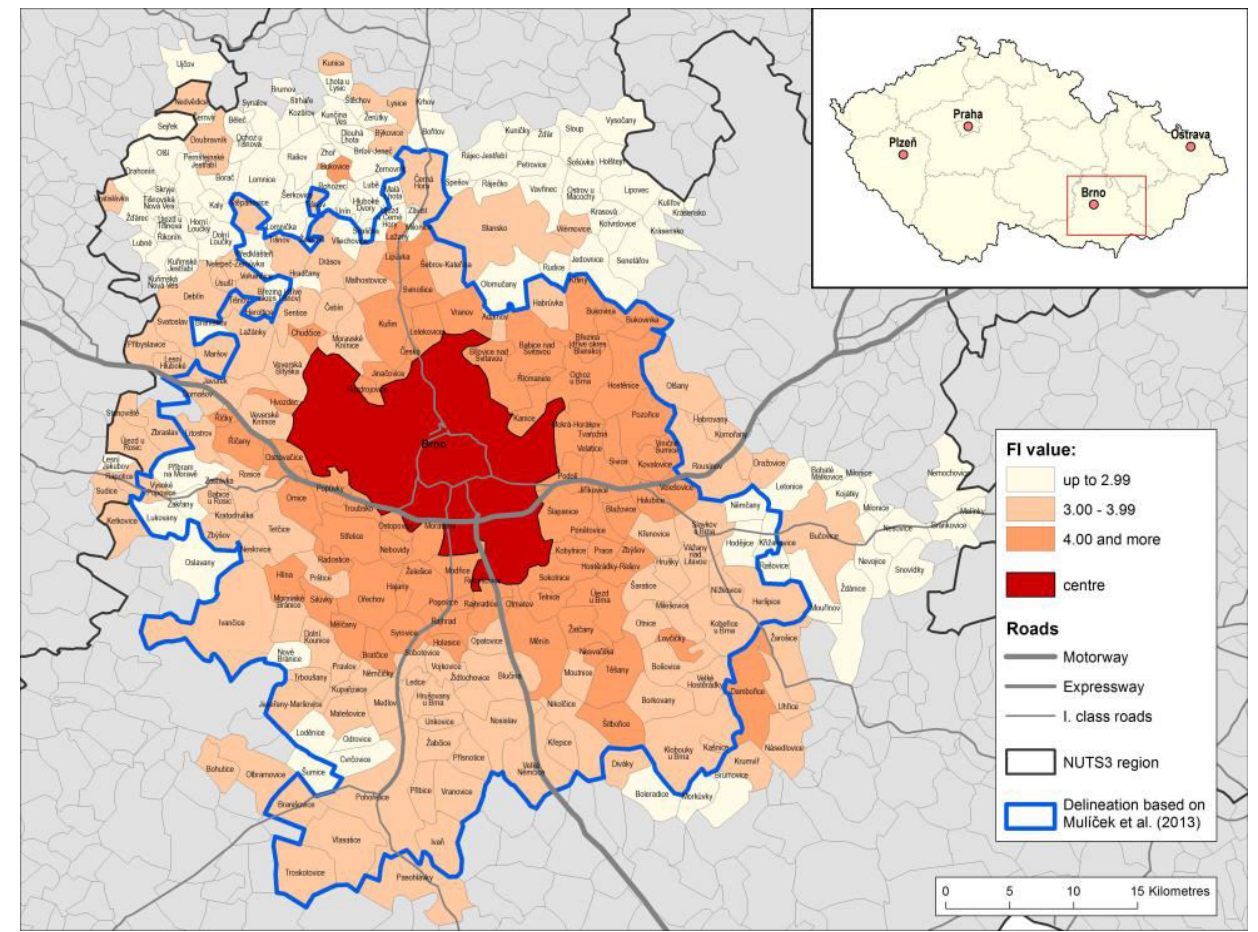

Fig. 2 Brno's metropolitan area (Source: original work) 


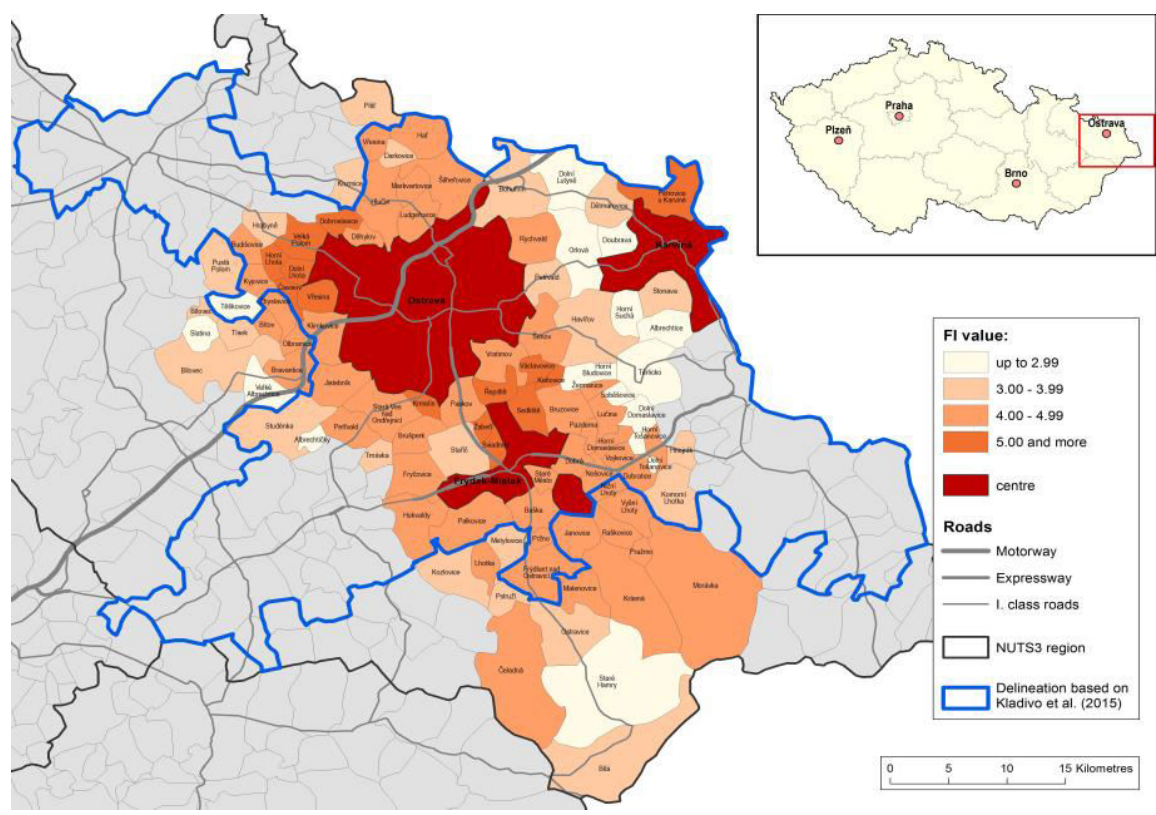

Fig. 3 Ostrava's metropolitan area (Source: original work)

As shown in Table 1., individual methods achieve - at least when considering the number of municipalities and inhabitants - different results. Setting a unified method to define such a complex organism as a metropolitan area, which could be used without attending to the differences between monocentric and polycentric structures, is potentially very problematic.

Table 1.

Metropolitan areas of Brno and Ostrava, based on other comparative methods

and selected works.

\begin{tabular}{|l|c|c|c|c|c|}
\hline \multirow{2}{*}{ Definition based on } & \multirow{2}{*}{$\begin{array}{c}\text { Related to the } \\
\text { year (date) }\end{array}$} & \multicolumn{2}{|c|}{ BMA } & \multicolumn{2}{c|}{ OMA } \\
\cline { 3 - 6 } & & $\begin{array}{c}\text { Number of } \\
\text { municipalities }\end{array}$ & $\begin{array}{c}\text { Number of } \\
\text { inhabitants }\end{array}$ & $\begin{array}{c}\text { Number of } \\
\text { municipalities }\end{array}$ & $\begin{array}{c}\text { Number of } \\
\text { inhabitants }\end{array}$ \\
\hline Proposed method by us & $\mathbf{2 0 1 1}$ & $\mathbf{2 9 0}$ & $\mathbf{7 1 1 ~ 0 9 1}$ & $\mathbf{1 0 3}$ & $\mathbf{7 6 8 8 5 3}$ \\
\hline Mulíček et al. & $\mathbf{2 0 1 1}$ & $\mathbf{1 6 7}$ & $\mathbf{6 0 9 1 1 4}$ & - & - \\
\hline Kladivo et al. & $\mathbf{2 0 1 1}$ & - & - & $\mathbf{1 2 4}$ & $\mathbf{9 7 0 5 5 8}$ \\
\hline Dvořák & 2011 & 305 & 719271 & 49 & 436076 \\
\hline Hruška-Tvrdý & 2010 & - & - & - & 1013912 \\
\hline OECD & 2010 & 245 & 639026 & 67 & 564380 \\
\hline Fixel et al. & 2009 & 96 & 507088 & - & - \\
\hline Hampl & 2004 & 292 & 589637 & 251 & 891759 \\
\hline Čermák a Kostelecký & 2001 & 133 & 514869 & 54 & 671947 \\
\hline
\end{tabular}

Source: original analysis based on the data from the Czech Statistical Office (2011), Dvoŕák (2015), Kladivo et al., (2015), Mulíček et al. (2013), Hruška-Tvrdý (2012), OECD (2013), Fixel et al. (2009), Malý lexikon obcí (2004), Čermák and Kostelecký (2004).

Based on the comparative analysis of these methods, we can highlight and discuss the following differences, even deficiencies, in the methods of Mulíček etal.(2013) and Kladivo et al.(2015) when compared with our method. Mulíček et al.(2013) versus our method:

- Use additional indicators connected to potential areas; our method uses only indicators related to existing strong connections within an area; 
- Use primary school commuting, which has only a small/local spatial range. Commuting to high school better reflects the connections on a higher hierarchic level;

- Do not deal with the possibility of a polycentric area, nor the possible presence of secondary centres;

- Their procedure is more complicated; the method requires specialized software (INTRAMAX) and even the programming of a special application (TTWA).

Kladivo et al. (2015) versus our method:

- Use a subjective choice of centres, based on population size and some other qualitative characteristics without setting a limit, thus it is not clear which method applies to which area;

- Add some secondary centres without sufficiently clear justification, giving an artificial impression of their position and significance as work commuting centres;

- Their choice of centres assumes the polycentric character of the area without reflecting the reciprocal, and often rather asymmetrical, connections between them;

- Do not deal with the level of functional integration of municipalities within the metropolitan area, and therefore do not consider the strength of the relation between a municipality and the centre/centres.

\section{CONCLUSION}

The countries of CEE, Czech Republic including, lack an established, unified method for defining metropolitan areas. In the current programming period, 2014-2020, the approach to each definition has been individual. The extent and structure of metropolitan areas defined using the ITI tool are considerably changeable which cannot be considered ideal, i.e. in terms of comparing indicators and evaluating developing effects. It is possible to apply the new method presented in this article to any area with diametrically different settlement structures (monocentric or polycentric), as shown using Brno and Ostrava metropolitan areas as case studies. Verifying the existence of a greater number of centres interconnected functional relationship leads, in the case of a polycentric settlement system, to a significantly more accurate definition of a metropolitan area. The application of the method is also fairly straightforward; it does not require either the use of special software, or any programming of special algorithms. Certain disadvantages seem to be that the method does not consider less significant connections within a metropolitan area (usually of a tangential character i.e. heading out of the centre of a metropolitan area); or control the level of self-containment (the ratio of interactions within the area to the interactions at its borders); as are considered by some of the more complex procedures. The method is not limited to using commuting to work as an indicator, but can be used for other available indicators too if these have sufficient corresponding value in terms of inter-settlement connections in the researched area (migration, commuting for a certain type of service and so on). In this case, the result would be not just the definition of a metropolitan area, but also of the functional interactions of the territorial unit used (in this case the municipality), and this has the potential to be used in other, more detailed analyses of the area -area not primarily bound to the territory of given country, but with respect to the settlement system and territorial specifics. Comparison and discussion of the presented methodological approaches are not an a priori criticism of the methods used. Their authors were often forced to adapt to the "recommendation" of the sponsoring institutions and to alter the results achieved based on correct data and approaches according to their preferences. Our criticism is, therefore, directed both towards the inability of both central (state) 
coordination of the ITI and towards the municipal and regional authorities which are supposed to apply them to the metropolitan areas in the territory. Clearly, the process will be very difficult and lengthy in transitive economies that are not used to the functionality and potential institutionalization of metropolitan areas.

\section{ACKNOWLEDGEMENT}

This contribution was supported by an internal grant of the Faculty of Economics and Administration, Masaryk University, entitled "Metropolitan Processes Formating Traditional City Structure: an Example of Brno Metropolitan Area" (MUNI/A/0976/2016) and by Czech Science Foundation under Grant "Spatial Uncertainty and Fuzzy Regional Systems: Identification, Analysis and Implications of Pulsating Functional Regions" (No. 16-13502S).

\section{R E F E R E N C E S}

Adams, J.S., VanDrasek, B.J. \& Phillips, E.G. (1999): Metropolitan Area Definition in the United States. Urban Geography, 20 (8), 695-726.

Benedek, J. (2016) The Role of Urban Growth Poles un Regional Policy: The Romanian Case. Procedia - Social and Behavioral Science, 223, 285-290.

Berry, B. J. L. (1973) Growth Centres in the American Urban System. Cambridge, Mass: Ballinger Publishing Company,.

Berry, B. J. L., Goheen, P. G. \& Goldstein, H. (1968) Metropolitan Area Definition: A Re-evaluation of Concept and Statistical Practice.. Washington, DC: Bureau of the Census. Report number:28

Boix, R., Veneri, P. \& Almenar, V. (2012) Polycentric Metropolitan Areas in Europe: Towards a Unified Proposal of Delimitation. In: Vázquez, E.F. \& Morollon, F.R. (eds.) Defining the Spatial Scale in Modern Regional Analysis. Advances in Spatial Science, 1430-9602, Berlin, Springer Berlin Heidelberg, 45-70.

Brezzi, M., Piacentini, M. \& Sanchez-Serra, D. (2012) Measuring Metropolitan Areas: A Comparative Approach in OECD Countries. In: Vázquez, E.F. \& Morollon, F.R. (eds.) Defining the Spatial Scale in Modern Regional Analysis. Advances in Spatial Science, 1430-9602, Berlin, Springer Berlin Heidelberg, 71-89.

Burgess E.W. (1924). The Growth of the City: An Introduction to a Research Project. Publications of the American Sociological Society, 18, 85-97.

Čermák, Z., Hampl, M. \& Müller, J. (2009) Současné tendence vývoje obyvatelstva metropolitních areálů v Česku: dochází k významnému obratu? Geografie- Sbornik CGS, 114 (1), 37-51.

Cheshire, P.C. \& Hay, D.J. (1989) Urban Problems in Western Europe: An Economic Analysis. London, Unwin Hyman.

Coombes, M., Dixon, J. S., Goddard, J.B., Openshaw, S. \& Taylor, P.J. (1982) Functional regions for the population census of Great Britain. In: Herbert, D.T. \& Johnston, R.J. (eds.) Geography and the Urban Environment: Progress in Research and Applications. Chichester: Wiley, Chichister, pp. 63-112.

Coombes, M.G., Dixon, J.S., Goddard, J.B., Openshaw, S. \& Taylor, P.J. (1978) Towards a More Rational Consideration of Census Areal Units: Daily Urban System in Britain. Environmental and Planning A, 10, 565-574.

Czech Statistical Office (2004). Small Lexicon of Municipalities - 2004. [Online]. Available from: https://www.czso.cz/csu/czso/maly-lexikon-obci-cr-2004-ggpshw1ojm. [Accessed 21 March 2016].

Czech Statistical Office (2011). Census 2011. [Online]. Available from: https://vdb.czso.cz/sldbvo/\#! stranka=podletematu\&tu $=0 \&$ th $=\& v$ seuzemi $=$ null $\& v=1 \& v o=$ null $\& v$ oid=. [Accessed 21st March 2016]. 
Dahmann, D. C. (1999): New Approaches to Delineating Metropolitan and Nonmetropolitan Settlement: Geographers drawing the line. Urban Geography, 20 (8), 683-694.

Dostál, P. \& Hampl, M. (2002) Metropolitan Areas in Transformation of Regional Organisation in the Czech Republic. Acta Universitatis Carolinae. Geographica, 37 (2), 133-155.

Duranton, G. (2015a) A proposal to delineate metropolitan areas in Colombia. Desarrollo y Sociedad, 75, 223-264.

Duranton, G. (2015b) Delineating Metropolitan Areas: Measuring Spatial Labour Market Networks Through Commuting Patterns. In: Watanabe, T., Uesugi, I., \& Ono, A. (eds.) The Economics of Interfirm Networks. Advances in Japanese Business and Economics, 2197-8859 4. Tokyo, Springer Japan, 107-133.

Dvořák, Z. (2015) Metropolitní oblasti v České republice: formování, vymezení, konkurence a výhody. [Diplomová práce]. Brno: Masarykova univerzita.

Fixel, J., Pech, Z. (2009) Územni studie aglomeračních vazeb města Brna a jeho okolí. [Online]. Available from: https://up.kr-jihomoravsky.cz/download/US/2231/US_BA.htm. [Accessed 1st April 2016].

García-Palomares, J.C. (2010) Urban Sprawl and Travel to Work: The Case of the Metropolitan Area of Madrid. Journal of Transport Geography, 18 (2), 197-213.

Göddecke-Stellmann, J. (2011) Metropolitan Areas in Europe. In: Forum of Federations and European Committee of the Regions, Workshop on the "Governance of Metropolitan Regions in Federal Systems", Brussels, Committee of the Regions, pp. 111-123.

Hall, P. \& Hay, D. (1980) Growth Centres in the European Urban System. Heinemann Educational Books. Oakland, University of California Press.

Hall, P., Gracey, H., Drewett, R. \& Thomas, R. (1973), The Containment of Urban England, Vol. II, Beverly Hills, Sage Publications.

Hampl, M. (2005) Geografická organizace společnosti v České republice: Transformačni procesy a jejich obecný kontext. Praha, Univerzita Karlova.

Hruška-Tvrdý, L. (2012) Změny ve struktuře osidlení a jejich dopad na rozvoj měst a regionů: pohled prostorové sociologie s využitím multikriteriálních analýz. Ostrava, Accendo - Centrum pro vědu a výzkum.

Kanemoto, Y. \& Kurima, R. (2006) Urban Employment Areas: Defining Japanese Metropolitan Areas and Constructing the Statistical Database for Them. In: Okabe, A. (ed.) GIS-based Studies in the Humanities and Social Sciences. Boca Raton, Taylor \& Francis, 85-97.

Kawashima, T. \& Korcelli, P. (eds.) (1982): Human Settlement Systems: Spatial Patterns and Trends. IIASA Collaborative proceedings. CP-82-S1. Laxenburg: IIASA.

Kladivo P., Ptáček, P. \& Roubínek, P. (2015) ITI Ostravské aglomerace : Vymezení území Ostravské aglomerace. [Online]. Available from: http://www.rr-moravskoslezsko.cz/file/4358_1_1/.pdf. [Accessed 11th April 2016].

Klapka, P., Halás, M., Netrdová, P. \& Nosek, M. (2016) The Efficiency of Areal Units in Spatial Analysis: Assessing the Performance of Functional and Administrative Regions. Moravian Geographical Reports, 24 (2), 47-59.

Kostelecký, T. \& Čermák, D. (2004) Metropolitan areas in the Czech republic - Definitions, Basic Characteristics, Patterns of Suburbanisation and Their Impact on Political Behaviour. Praha: Sociologický ústav Akademie věd České republiky.

Liu, L., Dong, X. \& Chi, S. (2010) Quantitative Delimitation of Metropolitan Areas Based on a Synthetic Metod: Case Study in the Lanzhou Metropolitan Area. Journal of Urban Planning and Development, 136 (4), 357-364.

Malý, J. \& Mulíček, O. (2016). European Territorial Cohesion Policies: Parallels to Socialist Central Planning? Moravian Geographical Reports, 24 (1), 14-26.

Manley, E. (2014) Identifying Functional Urban Regions Within Traffic Flow. Regional Studies, Regional Science, 1 (1), 40-2. 
Mulíček, O. (ed.) (2013) Vymezeni funkčního územi Brněnské metropolitni oblasti a Jihlavské sídelni aglomerace. [Online]. Available from: http://www.brno.cz/fileadmin/user_upload/sprava_mesta/ Strategie_pro_Brno/doplnujici_studi e/BMO_JSA_vymezeni_2013_web.pdf. [Accessed 1st August 2016].

Nystuen, J.D. \& Dacey, M.F. (1961) A Graph Theory Interpretation of Nodal Regions. Papers in Regional Science, 7 (1), 29-42.

OECD (2013) Regional Statistics and Indicators: Definition of Functional Urban Areas for the OECD Metropolitan Database. [Online]. Available from: http://www.oecd.org/gov/regionalpolicy/Definition-of-Functional-Urban-Areas-for-theOECDmetropolitan-database.pdf. [Accessed 1st august 2016].

ÖIR (2006) The Role of Small and Medium-sized Town. Final Report of the ESPON Project 1.4.1. [Online]. Available from: https://www.espon.eu/export/sites/default/Documents/Projects/ESPON 2006Projects/StudiesScientificSupportProjects/SmallMediumCities/fr-1.4.1_revised-full.pdf.

[Accessed 1st august 2016].

Ouředníček, M., Šimon, M. \& Kopečná, M. (2015) The Reurbanisation Concept and its Utility for Contemporary Research on Post-socialist Cities: The Case of the Czech Republic. Moravian Geographical Reports, 23 (4), 26-35.

Pařil, V., Kunc, J., Šašinka, P., Tonev, P. \& Viturka, M. (2015) Agglomeration Effects of the Brno City (Czech Republic) as Exemplified by the Population Labour Mobility. Geographia Technica, 10 (1), 66-76.

Šašinka, P. (2014) Několik úvodních poznámek k problematice institucionalizace metropolitních oblastí v kontextu vývoje urbanizace v České republice. In Klímová, V., Žítek, V. (eds) XVII. mezinárodní kolokvium o regionálních vědách. Sborník př́spěvkủ. Brno: Masarykova univerzita, 677-682.

Sherill, K. (1976) Functional Urban Regions in Austria. International Institute for Applied Systems analysis (IIASA), Research memorandum, RM-76-71.

Sherill, K. (1977) Functional Urban Regions and Central Place Regions in the Federal Republic of Germany and Switzerland. International Institute for Applied Systems analysis (IIASA), Research memorandum, RM-77-17.

Swianiewicz P. \& Lackowska M. (2007) From Doing Nothing to Metropolitan Government Institutions? Governing Metropolitan Areas in Poland. In: Collin J. P and Robertson M. (eds.) Metropolitan Governance: Issues and Depictions of Experiments on Four Countries. Montreal, Les Presses de l'Universite Laval, 317-344.

Sýkora, L. \& Mulíček, O. (2009) The Micro-regional Nature of Functional Urban Areas (FUAs): Lessons from the Analysis of the Czech Urban and Regional System. Urban Research \& Practice, 2 (3), 287-307.

Tong, D. \& Plane, D.A. (2014) A New Spatial Optimization Perspective on the Delineation of Metropolitan and Micropolitan Statistical Areas. Geographical Analysis, 46 (3), 230-249.

Török, I. (2015) City Region and Socio-Spatial Polarization in Romania. Procedia Earth and Planetary Science, 15, 951-955.

Van Nuffel, N. (2007) Determination of the Number of Significant Flows in Origin-Destination Specific Analysis: The Case of Commuting in Flanders. Regional Studies, 41 (4), 509-524.

Veneri, P. (2013) The Identification of Sub-centres in Two Italian Metropolitan Areas: A Functional Approach. Cities, 31, 177-185.

Zhen F., Cao, Y., Qin, X. \& Wang, B. (2017) Delineation of an Urban Agglomeration Boundary Based on Sina Weibo Microblog 'Check-in' data: A Case Study of the Yangtze River Delta. Cities, 60, 180-191. 